\title{
Improvement of the Hydrogen-Release Features of Mg-Graphene Composite by Adding Nickel via Reactive Ball Milling
}

\author{
Eunho Choi ${ }^{1}$, Young Jun Kwak', and Myoung Youp Song ${ }^{2}$,* \\ ${ }^{1}$ Department of Materials Engineering, Graduate School, Chonbuk National University, Jeonju 54896, Republic of Korea \\ ${ }^{2}$ Division of Advanced Materials Engineering, Hydrogen \& Fuel Cell Research Center, Engineering Research Institute, Chonbuk \\ National University, Jeonju 54896, Republic of Korea
}

\begin{abstract}
The dehydrogenation rates of graphene-added Mg (named Mg-5graphene) were very low at $573 \mathrm{~K}$ and $593 \mathrm{~K}$. Ni was added to increase the dehydrogenation rates of graphene-added Mg. Samples (designated as $\mathrm{Mg}-2.5 \mathrm{Ni}-2.5$ graphene) with a composition of $95 \mathrm{wt} \% \mathrm{Mg}+2.5 \mathrm{wt} \% \mathrm{Ni}+2.5 \mathrm{wt} \%$ graphene were prepared by milling in hydrogen (reactive ball milling). $\mathrm{Mg}-2.5 \mathrm{Ni}-2.5$ graphene had significantly higher initial hydrogenation and dehydrogenation rates and much greater amounts of hydrogen absorbed and released after $60 \mathrm{~min}, \mathrm{H}_{\mathrm{a}}(60 \mathrm{~min})$ and $\mathrm{H}_{\mathrm{d}}(60 \mathrm{~min})$, than $\mathrm{Mg}$-5graphene. The addition of $\mathrm{Ni}$ lowered the magnesium hydride decomposition temperature from $683 \mathrm{~K}$ to $581 \mathrm{~K}$. The activation of Mg-2.5Ni-2.5graphene was finished after the second hydrogenation-dehydrogenation cycle $(\mathrm{n}=2)$. Mg-2.5Ni-2.5graphene had a very high efficient capacity of stored hydrogen (the amount of hydrogen absorbed after $60 \mathrm{~min}$ ) higher than $7 \mathrm{wt} \%$ (7.07 wt\% at $573 \mathrm{~K}$ in 12 bar $\mathrm{H}_{2}$ at $\mathrm{n}=1$ ). At $\mathrm{n}=1$, the quantities of hydrogen released by $\mathrm{Mg}-2.5 \mathrm{Ni}-2.5$ graphene were $0.26 \mathrm{wt} \% \mathrm{H}$ after $2.5 \mathrm{~min}$ and $3.34 \mathrm{wt} \% \mathrm{H}$ after $60 \mathrm{~min}$ at $573 \mathrm{~K}$ in 1.0 bar $\mathrm{H}_{2}$.
\end{abstract}

(Received June 28, 2019; Accepted August 20, 2019)

Keywords: hydrogen absorbing materials, reactive ball milling, scanning electron microscopy (SEM), X-ray diffraction, graphene and $\mathrm{Ni}$ addition

\section{INTRODUCTION}

The highly estimated potential of magnesium hydride as a reversible hydrogen absorption and release medium has attracted many researchers' attention [1-4]. Magnesium (Mg) has a large hydrogen-absorbing capacity (about $7.6 \mathrm{wt} \%$ ) and is of relatively low price. However, it is known that the hydrogenation of $\mathrm{Mg}$ halts after the formation of a small quantity of hydride and the hydrogenation rate decreases very sharply. Much research has been conducted on increasing the hydrogenation and dehydrogenation rates of magnesium [5-9] by adding metals to magnesium or magnesium hydride [10, 11], by preparing $\mathrm{Mg}$-containing compounds such as $\mathrm{Mg}_{51} \mathrm{Zn}_{20}$ [12] and $\mathrm{Mg}_{2} \mathrm{FeH}_{6}$ [13] and $\mathrm{Mg}_{2} \mathrm{CoH}_{5}$ [13], and by using various processing like cold forging [14] and filing [15].

Among the studies in which carbon materials have been

- 최은호: 석사과정, 곽영준: 연구원, 송명엽: 교수 *Corresponding Author: Myoung Youp Song [Tel: +82-63-270-2379, E-mail: songmy@jbnu.ac.kr ] Copyright (c) The Korean Institute of Metals and Materials added, Jang et al. [16] synthesized $\mathrm{MgH}_{\mathrm{x}}$ by milling in hydrogen for $96 \mathrm{~h}$ and prepared $\mathrm{MgH}_{\mathrm{x}}$-graphene composites by adding 5 or $10 \mathrm{wt} \%$ graphene to $\mathrm{MgH}_{\mathrm{x}}$ via milling for 72 $h$ in a planetary ball mill in argon. They reported that at 423 $\mathrm{K}$, the added graphene was found to play the role of a hydrogen absorbent as well as a catalyst. Huot et al. [17] investigated the activation characteristics of graphite modified pure $\mathrm{Mg}, \mathrm{Mg}_{2} \mathrm{Ni}, \mathrm{Ti}, \mathrm{V}$, and FeTi by adding $10 \mathrm{wt} \%$ of graphite and milling the mixture during $30 \mathrm{~min}$. The activation characteristics of the graphite-containing materials were dramatically improved. The authors proposed that graphite prevents a new oxide layer of the surface of the materials from being formed once the native oxide layer is broken during milling for sample preparation. Spassov et al. [18] synthesized 75 at $\% \mathrm{MgH}_{2}+25$ at $\% \mathrm{C}$ composites by melding different carbons, such as carbon black, nanodiamonds, and amorphous carbon soot, to $\mathrm{MgH}_{2}$ in a ball mill. They insisted that the inclusion of the different carbons made a difference in the hydrogenation and dehydrogenation features of the $\mathrm{Mg}-\mathrm{C}$ composites and that the added carbons are 
supposed to catalyze the hydrogenation and dehydrogenation of the composites as well as protect magnesium from oxidation. Among the composites, $\mathrm{Mg}$-carbon black revealed the best hydrogenation properties - low hydrogenation temperature and relatively rapid hydrogenation kinetics.

In our previous work, graphene was added to increase the hydrogenation and dehydrogenation rates of $\mathrm{Mg}$. The hydrogenation rates of $\mathrm{Mg}$ were increased by adding graphene, but the dehydrogenation rates of graphene-added $\mathrm{Mg}$ were very low at $573 \mathrm{~K}$ and $593 \mathrm{~K}[19,20]$. It is reported that $\mathrm{Ni}$ addition increases the hydrogenation and dehydrogenation rates of $\mathrm{Mg}$ [21-24].

In this work, $\mathrm{Ni}$ was used as an additive to increase the dehydrogenation rates of graphene-added $\mathrm{Mg}$. The sum of all the additives was $5 \mathrm{wt} \%$. Samples with a composition of 95 $w t \% \mathrm{Mg}+2.5 \mathrm{wt} \% \mathrm{Ni}+2.5 \mathrm{wt} \%$ graphene were prepared by ball milling in hydrogen (reactive ball milling). The samples were designated as $\mathrm{Mg}-2.5 \mathrm{Ni}-2.5$ graphene. The hydrogenation and dehydrogenation features of the synthesized specimens were investigated and compared with those of 95 $\mathrm{wt} \% \mathrm{Mg}+5 \mathrm{wt} \%$ graphene (named $\mathrm{Mg}-5$ graphene) reported in our previous work [11].

\section{MATERIALS AND METHODS}

The beginning materials were pure $\mathrm{Mg}$ powder $(-20+100$ mesh, purity 99.8\%, Alfa Aesar), Ni (Nickel powder APS, $2.2-3.0 \mu \mathrm{m}$, purity $99.9 \%$, C typically $<0.1 \%$, Alfa Aesar), and graphene (3-10 multi-layer graphene, length 5-10 $\mu \mathrm{m}$, purity $\geq 99 \mathrm{wt} \%$, thickness $3-6 \mathrm{~nm}$, specific surface area 150 $\mathrm{m}^{2} / \mathrm{g}$, producing method chemical exfoliation proprietary method, Carbon Nano-material Technology Co., Ltd).

Reactive ball milling was done in a planetary ball mill (Planetary Mono Mill; Pulverisette 6, Fritsch) for $12 \mathrm{~h}$. A mixture of $\mathrm{Mg}$ (7.6 g) and $\mathrm{Ni}(0.2 \mathrm{~g})$ was melded with 105 hardened steel balls (total weight $=360 \mathrm{~g}$ ) with a disc revolution speed of $400 \mathrm{rpm}$ in hydrogen of about 12 bar, which was replenished every two hours $[25,26]$.

To prepare $\mathrm{Mg}-2.5 \mathrm{Ni}-2.5$ graphene, the inclusion of graphene $(0.2 \mathrm{~g})$ to the pre-milled mixture of $\mathrm{Mg}(7.6 \mathrm{~g})$ and $\mathrm{Ni}(0.2 \mathrm{~g})$ was also carried out for $30 \mathrm{~min}$ under conditions similar to those for the preparation of the pre-milled mixture of $\mathrm{Mg}(7.6 \mathrm{~g})$ and $\mathrm{Ni}(0.2 \mathrm{~g})$.
The variation of absorbed or released hydrogen amount was measured with time in a Sievert's type hydrogenation and dehydrogenation apparatus explained previously [26]. During the measurements, the hydrogen pressures in the specimen container were kept nearly constant by replenishing the absorbed hydrogen from a standard volume reservoir (a small reservoir of a known volume) during hydrogenation and by taking the released hydrogen away to the standard volume reservoir during dehydrogenation. $0.5 \mathrm{~g}$ of the specimens was used for the measurement of the variation with time of the absorbed or released hydrogen amount. After we measured the absorbed hydrogen amount in 12 bar $\mathrm{H}_{2}$ for $1 \mathrm{~h}$ and then the released hydrogen amount in 1.0 bar $\mathrm{H}_{2}$ for $1 \mathrm{~h}$, the sample was dehydrogenated at $623 \mathrm{~K}$ in a vacuum for $1.5 \mathrm{~h}$ to fully dehydrogenate the sample.

The phases formed in the specimens after reactive ball milling or after hydrogenation-dehydrogenation cycling were analyzed from X-ray diffraction (XRD) patterns obtained with $\mathrm{Cu} \mathrm{K} \alpha$ radiation in a powder diffractometer (Rigaku D/ MAX 2500). To observe the microstructures of the specimens after reactive ball milling or after hydrogenationdehydrogenation cycling, a scanning electron microscope (SEM) (JSM-5900) operated at $15 \mathrm{kV}$ and a high-resolution transmission electron microscope (HR-TEM) (JEM-2010) operated at $200 \mathrm{kV}$ were used.

\section{RESULTS AND DISCUSSION}

The amount of hydrogen absorbed by the sample, $\mathrm{H}_{\mathrm{a}}$, was calculated using the sample weight as a standard. The amount of hydrogen released by the sample, $\mathrm{H}_{\mathrm{d}}$, was also calculated using the sample weight as a standard. $\mathrm{H}_{\mathrm{a}}$ and $\mathrm{H}_{\mathrm{d}}$ were given in the unit of $\mathrm{wt} \% \mathrm{H}$.

Figure 1 shows the curves of $\mathrm{H}_{\mathrm{a}}$ as a function of time $\mathrm{t}$ in 12 bar $\mathrm{H}_{2}$ and the curves of $\mathrm{H}_{\mathrm{d}}$ as a function of time $\mathrm{t}$ in 1.0 bar $\mathrm{H}_{2}$ at $573 \mathrm{~K}$ at the third hydrogenation-dehydrogenation cycle $(n=3)$ for $\mathrm{Mg}-5$ graphene and $\mathrm{Mg}-2.5 \mathrm{Ni}-2.5$ graphene. The initial hydrogenation rate of $\mathrm{Mg}-5$ graphene is relatively high, and the hydrogenation rate of $\mathrm{Mg}-5$ graphene decreases as the time elapses. The initial hydrogenation rate of $\mathrm{Mg}$ $2.5 \mathrm{Ni}-2.5$ graphene is very high, and the hydrogenation rate of $\mathrm{Mg}-2.5 \mathrm{Ni}-2.5$ graphene decreases as the hydrogenation progresses. Mg-2.5Ni-2.5graphene has a much higher initial 


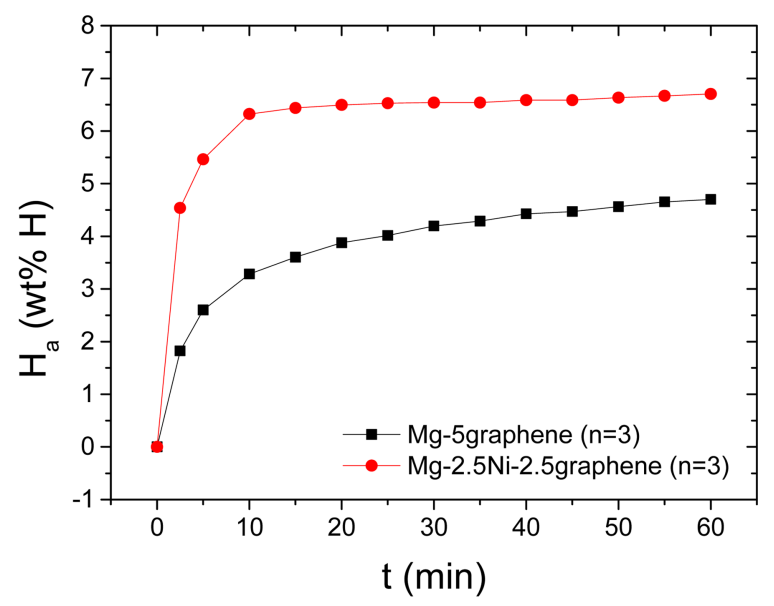

(a)

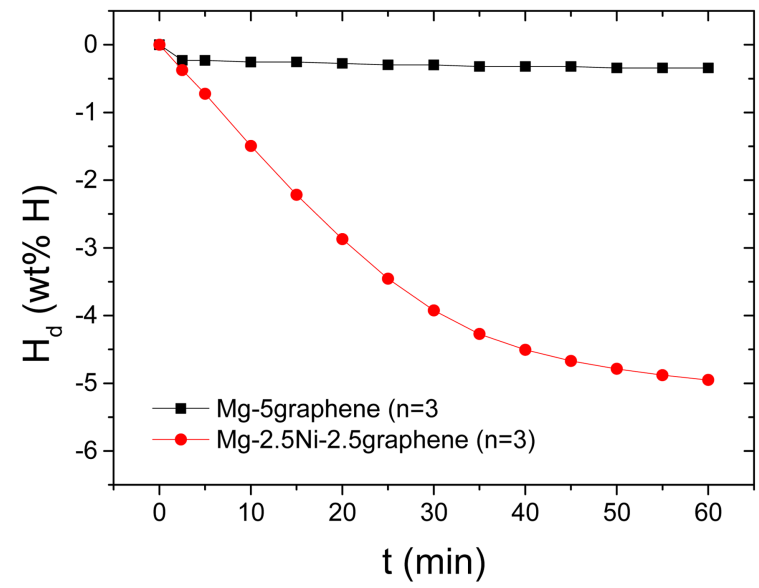

(b)

Fig. 1. (a) curves of $\mathrm{H}_{\mathrm{a}}$ as a function of $\mathrm{t}$ in 12 bar $\mathrm{H}_{2}$ and (b) curves of $\mathrm{H}_{\mathrm{d}}$ as a function of $\mathrm{t}$ in 1.0 bar $\mathrm{H}_{2}$ at $573 \mathrm{~K}$ at the third hydrogenation-dehydrogenation cycle $(\mathrm{n}=3)$ for $\mathrm{Mg}-5$ graphene and Mg-2.5Ni-2.5graphene.

hydrogenation rate and a significantly greater amount of hydrogen taken after $60 \mathrm{~min}, \mathrm{H}_{\mathrm{a}}(60 \mathrm{~min})$, than $\mathrm{Mg}$ 5 graphene. The quantities of hydrogen absorbed by $\mathrm{Mg}$ $2.5 \mathrm{Ni}-2.5$ graphene are $4.54 \mathrm{wt} \% \mathrm{H}$ after $2.5 \mathrm{~min}, 6.32 \mathrm{wt} \%$ $\mathrm{H}$ after $10 \mathrm{~min}$, and $6.70 \mathrm{wt} \% \mathrm{H}$ after $60 \mathrm{~min}$. The quantities of hydrogen absorbed by Mg-5graphene are 1.82, 3.28, and $4.70 \mathrm{wt} \% \mathrm{H}$ after $2.5,10$, and $60 \mathrm{~min}$, respectively. The initial dehydrogenation rate of $\mathrm{Mg}$-5graphene is very low, and the dehydrogenation rate of Mg-5graphene is also low after $2.5 \mathrm{~min}$. The initial dehydrogenation rate of $\mathrm{Mg}-2.5 \mathrm{Ni}-$ 2.5 graphene is relatively high, and the dehydrogenation rate of Mg-2.5Ni-2.5graphene decreases as the dehydrogenation progresses. Mg-2.5Ni-2.5graphene has a higher initial

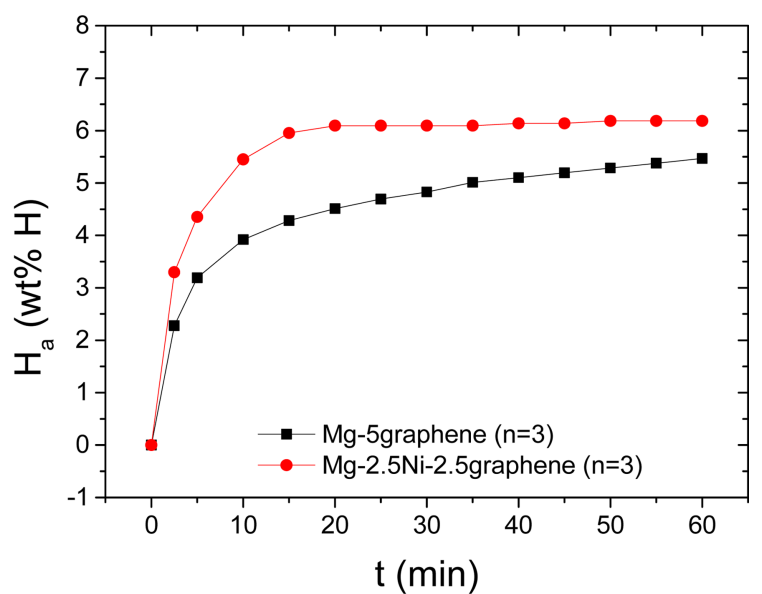

(a)

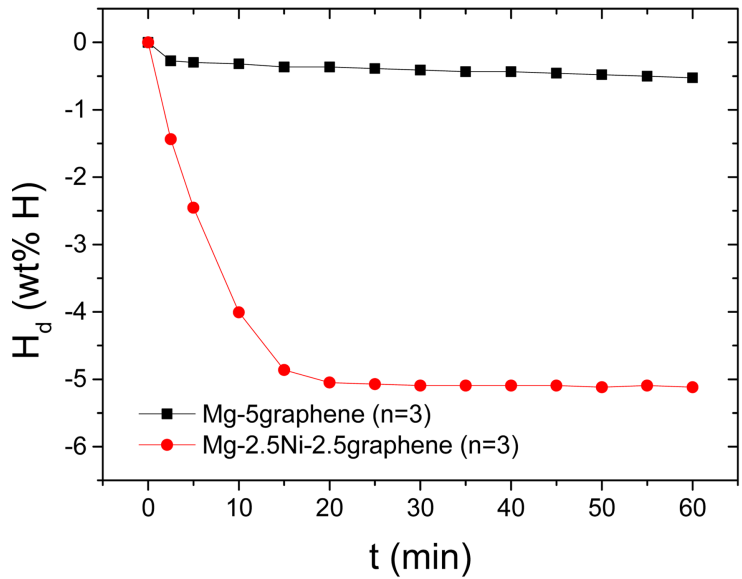

(b)

Fig. 2. (a) curves of $\mathrm{H}_{\mathrm{a}}$ as a function of $\mathrm{t}$ in 12 bar $\mathrm{H}_{2}$ and (b) curves of $\mathrm{H}_{\mathrm{d}}$ as a function of $\mathrm{t}$ in 1.0 bar $\mathrm{H}_{2}$ at $593 \mathrm{~K}$ at the third hydrogenation-dehydrogenation cycle for $\mathrm{Mg}-5$ graphene and $\mathrm{Mg}$ 2.5Ni-2.5graphene.

dehydrogenation rate and a significantly greater amount of hydrogen released for $60 \mathrm{~min}, \mathrm{H}_{\mathrm{d}}(60 \mathrm{~min})$, than $\mathrm{Mg}$ 5 graphene. The quantities of hydrogen released by $\mathrm{Mg}$ 2.5 $\mathrm{Ni}-2.5$ graphene are $0.37 \mathrm{wt} \% \mathrm{H}$ after $2.5 \mathrm{~min}, 1.50 \mathrm{wt} \%$ $\mathrm{H}$ after $10 \mathrm{~min}$, and $4.95 \mathrm{wt} \% \mathrm{H}$ after $60 \mathrm{~min}$. The quantities of hydrogen released by Mg-5graphene are $0.23,0.25$, and $0.34 \mathrm{wt} \% \mathrm{H}$ after $2.5,10$, and $60 \mathrm{~min}$, respectively.

The curves of $\mathrm{H}_{\mathrm{a}}$ as a function of $\mathrm{t}$ in $12 \mathrm{bar}_{2}$ and the curves of $\mathrm{H}_{\mathrm{d}}$ as a function of $\mathrm{t}$ in 1.0 bar $\mathrm{H}_{2}$ at $593 \mathrm{~K}$ at $\mathrm{n}=3$ for $\mathrm{Mg}$-5graphene and $\mathrm{Mg}-2.5 \mathrm{Ni}-2.5$ graphene are shown in Fig. 2. The initial hydrogenation rate of $\mathrm{Mg}-5$ graphene is relatively high, and the hydrogenation rate of $\mathrm{Mg}-5$ graphene decreases as the time elapses. The initial hydrogenation rate 
of $\mathrm{Mg}-2.5 \mathrm{Ni}-2.5$ graphene is very high, and the hydrogenation rate of $\mathrm{Mg}-2.5 \mathrm{Ni}-2.5$ graphene decreases as the hydrogenation progresses. Mg-2.5Ni-2.5graphene has a fairly higher initial hydrogenation rate and a fairly larger $\mathrm{H}_{\mathrm{a}}(60 \mathrm{~min})$ than $\mathrm{Mg}$ 5 graphene. The quantities of hydrogen absorbed by $\mathrm{Mg}$ 2.5Ni-2.5graphene are $3.30 \mathrm{wt} \% \mathrm{H}$ after $2.5 \mathrm{~min}, 5.45 \mathrm{wt} \%$ $\mathrm{H}$ after $10 \mathrm{~min}$, and $6.18 \mathrm{wt} \% \mathrm{H}$ after $60 \mathrm{~min}$. The quantities of hydrogen absorbed by Mg-5graphene are $2.28 \mathrm{wt} \% \mathrm{H}$ after $2.5 \mathrm{~min}, 3.92 \mathrm{wt} \% \mathrm{H}$ after $10 \mathrm{~min}$, and $5.47 \mathrm{wt} \% \mathrm{H}$ after $60 \mathrm{~min}$. The initial dehydrogenation rate of $\mathrm{Mg}-5$ graphene is very low, and the dehydrogenation rate of $\mathrm{Mg}-5$ graphene is also low after $2.5 \mathrm{~min}$. The initial dehydrogenation rate of $\mathrm{Mg}-2.5 \mathrm{Ni}-2.5$ graphene is very high, and the dehydrogenation rate of $\mathrm{Mg}-2.5 \mathrm{Ni}-2.5$ graphene decreases as the dehydrogenation progresses. Mg-2.5Ni-2.5graphene has a significantly higher initial dehydrogenation rate and a significantly greater $\mathrm{H}_{\mathrm{d}}(60$ min) than Mg-5graphene. The quantities of hydrogen released by $\mathrm{Mg}-2.5 \mathrm{Ni}-2.5$ graphene are $1.44 \mathrm{wt} \% \mathrm{H}$ after $2.5 \mathrm{~min}, 4.01$ $\mathrm{wt} \% \mathrm{H}$ after $10 \mathrm{~min}$, and $5.12 \mathrm{wt} \% \mathrm{H}$ after $60 \mathrm{~min}$. The quantities of hydrogen released by $\mathrm{Mg}-5$ graphene are 0.27 , 0.32 , and $0.53 \mathrm{wt} \% \mathrm{H}$ after $2.5,10$, and $60 \mathrm{~min}$, respectively.

Figure 3 shows the SEM micrographs at different magnifications of $\mathrm{Mg}-5$ graphene and $\mathrm{Mg}-2.5 \mathrm{Ni}-2.5$ graphene after reactive ball milling. $\mathrm{Mg}$-5graphene after reactive ball milling has no homogeneous particle size. Some parts of the particle surfaces are flat and other parts are undulated. The particle size of $\mathrm{Mg}-2.5 \mathrm{Ni}-2.5$ graphene after reactive ball milling is not homogeneous. The surfaces of the particles are smooth, and small particles are on large particles. The particles of $\mathrm{Mg}-2.5 \mathrm{Ni}-2.5$ graphene after reactive ball milling are much smaller than those of $\mathrm{Mg}-5$ graphene after reactive ball milling.

The XRD pattern of Mg-2.5Ni-2.5graphene after reactive ball milling is exhibited in Fig. 4. The sample contains $\beta$ $\mathrm{MgH}_{2}$ (JCPDS Card No.12-0697) and Mg (35-0821), and small amounts of $\gamma-\mathrm{MgH}_{2}$ (35-1184), graphene (75-1621), and Ni (04-0850). Reactive ball milling is believed to have induced microstrain and reduced the particle size, leading to the formation of broad peaks (strain broadening and particlesize broadening, respectively). The formation of broad peaks is deemed to heighten the background of the XRD pattern. The crystallite size of $\mathrm{Mg}$ was calculated as $13 \mathrm{~nm}$ using the Scherrer formula.

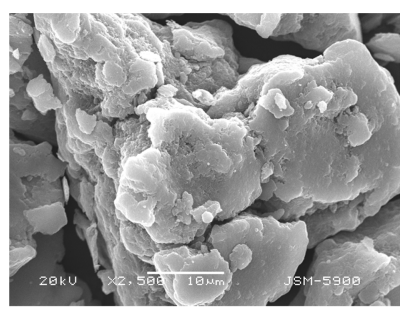

(a)

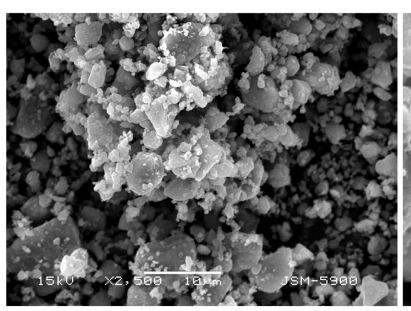

(c)

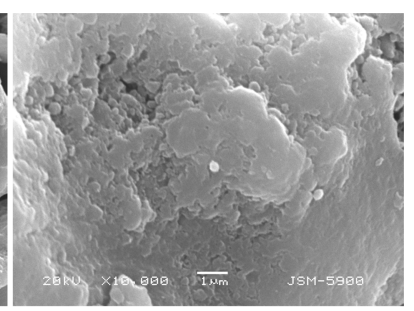

(b)

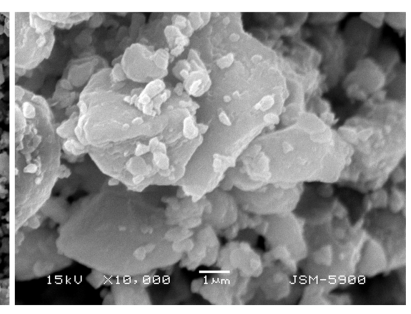

Fig. 3. SEM micrographs at different magnifications of (a, b) Mg5 graphene and (c, d) $\mathrm{Mg}-2.5 \mathrm{Ni}-2.5$ graphene after reactive ball milling.

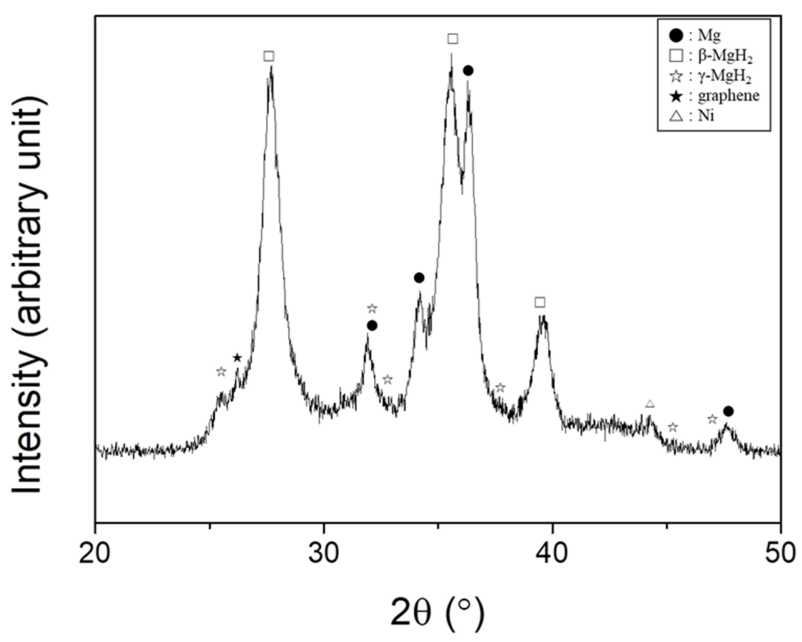

Fig. 4. XRD pattern of Mg-2.5Ni-2.5graphene after reactive ball milling.

Figure 5 shows the curves of the released hydrogen quantity $\mathrm{H}_{\mathrm{d}}$ as a function of temperature for $\mathrm{Mg}-5$ graphene and $\mathrm{Mg}-2.5 \mathrm{Ni}-2.5$ graphene when the as-prepared sample was heated at a rate of $5 \sim 6 \mathrm{~K} / \mathrm{min}$. Mg-5graphene begins to release hydrogen at $683 \mathrm{~K}$. The temperature increases up to $695 \mathrm{~K}$ and decreases to $688 \mathrm{~K}$. The decrease in temperature from $695 \mathrm{~K}$ to $688 \mathrm{~K}$ is believed to result from the higher decrease rate in temperature due to hydrogen release than the increase rate in temperature due to heating. The total released hydrogen quantity is $1.07 \mathrm{wt} \%$. Mg-2.5Ni-2.5graphene begins 


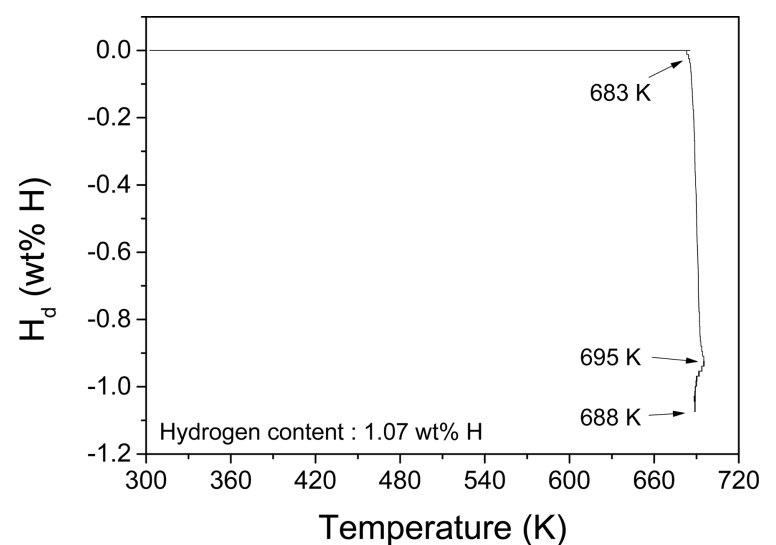

(a)

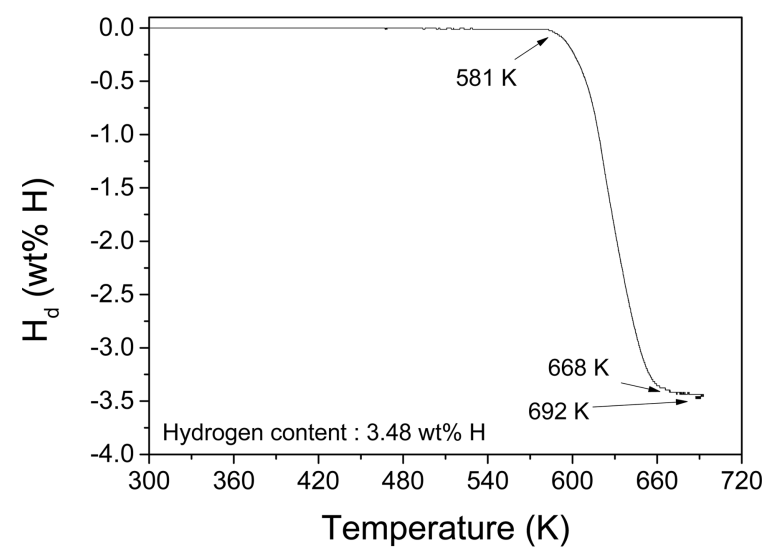

(b)

Fig. 5. Curves of released hydrogen quantity $\mathrm{H}_{d}$ as a function of temperature for (a) Mg-5graphene and (b) $\mathrm{Mg}-2.5 \mathrm{Ni}-2.5$ graphene when heated at a rate of $5 \sim 6 \mathrm{~K} / \mathrm{min}$.

to release hydrogen at $581 \mathrm{~K}$ and releases it very slowly from $668 \mathrm{~K}$ to $692 \mathrm{~K}$. The total released hydrogen quantity is 3.48 $\mathrm{wt} \%$. The addition of Ni lowers the temperature at which the sample begins to release hydrogen (the magnesium hydride decomposition temperature) from $683 \mathrm{~K}$ to $581 \mathrm{~K}$ and increases the total amount of released hydrogen.

The variation in the curve of $\mathrm{H}_{\mathrm{a}}$ as a function of $\mathrm{t}$ at $573 \mathrm{~K}$ in 12 bar $\mathrm{H}_{2}$ with the number of hydrogenation-dehydrogenation cycles, $\mathrm{n}$, for Mg-2.5Ni-2.5graphene is shown in Fig. 6. From $\mathrm{n}=1$, the initial hydrogenation rate of $\mathrm{Mg}-2.5 \mathrm{Ni}-2.5$ graphene is very high and the $\mathrm{H}_{\mathrm{a}}(60 \mathrm{~min})$ of $\mathrm{Mg}-2.5 \mathrm{Ni}-2.5$ graphene is large. From $n=1$ to $n=2$, the initial hydrogenation rate increases very slightly, and the $\mathrm{H}_{\mathrm{a}}(60 \mathrm{~min})$ decreases slightly. At $n=2, n=3$, and $n=4$, the initial hydrogenation rates are similar, but the $H_{a}(60 \mathrm{~min})$ at $n=4$ is smaller than those at $n=1$ and $n=2$. At $n=1$, the quantities of hydrogen absorbed

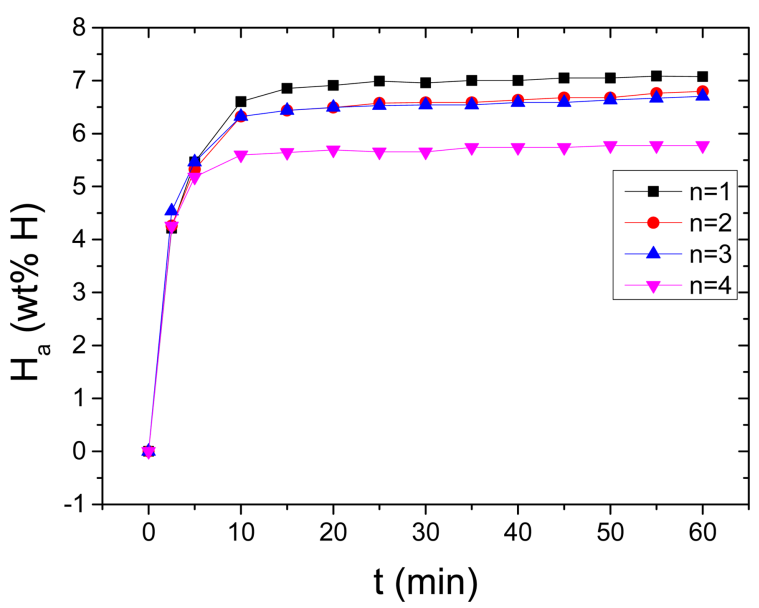

Fig. 6. Variation in the curve of $\mathrm{H}_{2}$ as a function of $t$ at $573 \mathrm{~K}$ in 12 bar $\mathrm{H}_{2}$ with the number of hydrogenation-dehydrogenation cycles, $\mathrm{n}$, for $\mathrm{Mg}-2.5 \mathrm{Ni}-2.5$ graphene.

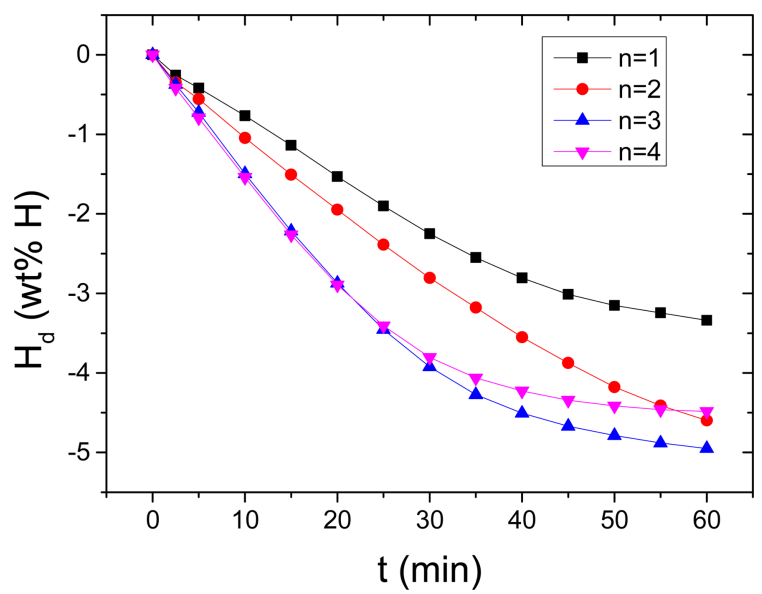

Fig. 7. Variation in the curve of $\mathrm{H}_{d}$ as a function of $t$ at $573 \mathrm{~K}$ in 1.0 bar $\mathrm{H}_{2}$ with the number of hydrogenation-dehydrogenation cycles, $\mathrm{n}$, for $\mathrm{Mg}-2.5 \mathrm{Ni}-2.5$ graphene.

by $\mathrm{Mg}-2.5 \mathrm{Ni}-2.5$ graphene are $4.21 \mathrm{wt} \% \mathrm{H}$ after $2.5 \mathrm{~min}, 6.60$ $\mathrm{wt} \% \mathrm{H}$ after $10 \mathrm{~min}$, and $7.07 \mathrm{wt} \% \mathrm{H}$ after $60 \mathrm{~min}$. At $\mathrm{n}=4$, the quantities of hydrogen absorbed by $\mathrm{Mg}-2.5 \mathrm{Ni}-$ 2.5graphene are 4.25, 5.60, and 5.77 wt $\% \mathrm{H}$ after 2.5, 10, and $60 \mathrm{~min}$, respectively.

We defined an efficient capacity of stored hydrogen as the quantity of hydrogen absorbed for $60 \mathrm{~min}$. Mg- $2.5 \mathrm{Ni}-$ 2.5graphene had a very high efficient capacity of stored hydrogen higher than $7 \mathrm{wt} \%(7.07 \mathrm{wt} \%$ at $573 \mathrm{~K}$ in 12 bar $\mathrm{H}_{2}$ at $\mathrm{n}=1$ ).

Figure 7 shows the variation in the curve of $H_{d}$ as a function of $\mathrm{t}$ at $573 \mathrm{~K}$ in 1.0 bar $\mathrm{H}_{2}$ with the number of 
hydrogenation-dehydrogenation cycles, $\mathrm{n}$, for $\mathrm{Mg}-2.5 \mathrm{Ni}-$ 2.5 graphene. From $n=1$, the initial dehydrogenation rate of Mg-2.5Ni-2.5graphene is high, and the $\mathrm{H}_{\mathrm{d}}(60 \mathrm{~min})$ of Mg$2.5 \mathrm{Ni}-2.5$ graphene is quite large. From $n=1$ to $n=4$, the initial dehydrogenation rate increases. The $\mathrm{H}_{\mathrm{d}}(60 \mathrm{~min})$ increases from $n=1$ to $n=3$ but decreases as $n$ increases from three to four. At the first cycle, the quantities of hydrogen released by $\mathrm{Mg}-2.5 \mathrm{Ni}-2.5$ graphene are $0.26 \mathrm{wt} \% \mathrm{H}$ after $2.5 \mathrm{~min}, 0.77$ $\mathrm{wt} \% \mathrm{H}$ after $10 \mathrm{~min}$, and $3.34 \mathrm{wt} \% \mathrm{H}$ after $60 \mathrm{~min}$. At $\mathrm{n}=3$, the quantities of hydrogen released by $\mathrm{Mg}-2.5 \mathrm{Ni}-$ 2.5 graphene are $0.37,1.50$, and $4.95 \mathrm{wt} \% \mathrm{H}$ after $2.5,10$, and $60 \mathrm{~min}$, respectively.

Figure 6 and 7 reveal that the activation of $\mathrm{Mg}-2.5 \mathrm{Ni}-$ 2.5graphene is finished after $n=2$.

The variations in the curve of $\mathrm{H}_{\mathrm{a}}$ as a function of $\mathrm{t}$ in 12 bar $\mathrm{H}_{2}$ and the curve of $\mathrm{H}_{\mathrm{d}}$ as a function of $\mathrm{t}$ in 1.0 bar $\mathrm{H}_{2}$ with temperature $(523 \mathrm{~K}, 573 \mathrm{~K}$, and $623 \mathrm{~K})$ at $\mathrm{n}=3$ for $\mathrm{Mg}$ 2.5Ni-2.5graphene are given in Fig. 8. With the increase in the temperature from $573 \mathrm{~K}$ to $593 \mathrm{~K}$, the initial hydrogenation rate and the $\mathrm{H}_{\mathrm{a}}(60 \mathrm{~min})$ decrease slightly. The increase in the temperature from $593 \mathrm{~K}$ to $623 \mathrm{~K}$ significantly decreases the initial hydrogenation rate and the $\mathrm{H}_{\mathrm{a}}(60 \mathrm{~min})$. At $573 \mathrm{~K}$, the quantities of hydrogen absorbed by $\mathrm{Mg}-2.5 \mathrm{Ni}-$ 2.5graphene are $4.54 \mathrm{wt} \% \mathrm{H}$ after $2.5 \mathrm{~min}, 6.32 \mathrm{wt} \% \mathrm{H}$ after $10 \mathrm{~min}$, and $6.70 \mathrm{wt} \% \mathrm{H}$ after $60 \mathrm{~min}$. At $623 \mathrm{~K}$, the quantities of hydrogen absorbed by $\mathrm{Mg}-2.5 \mathrm{Ni}-2.5$ graphene are $1.40,2.47$, and $4.33 \mathrm{wt} \% \mathrm{H}$ after $2.5,10$, and $60 \mathrm{~min}$, respectively. The driving force for hydrogenation is related to the gap between the pressure for hydrogenation (12 bar $\mathrm{H}_{2}$ in the present work) and the equilibrium plateau hydrogen pressure at a hydrogenation temperature. The equilibrium hydrogen pressures at the plateaus of the pressurecomposition isotherms for $\mathrm{Mg}-\mathrm{H}_{2}$ system are 1.55 bar, 2.69 bar, and 7.28 bar at $573 \mathrm{~K}, 593 \mathrm{~K}$, and $623 \mathrm{~K}$, respectively, [28]. The driving forces for hydrogenation of $\mathrm{Mg}$ are thus 10.45 bar, 9.31 bar, and 4.72 bar, respectively, at $573 \mathrm{~K}$, $593 \mathrm{~K}$ and $623 \mathrm{~K}$. Decrease in the driving forces for hydrogenation of $\mathrm{Mg}$ with the increase in temperature is thus believed to decrease the initial hydrogenation rate and the $\mathrm{H}_{\mathrm{a}}$ (60 $\mathrm{min}$ ), even though the effect of temperature increase is believed to increase them. A small decrease in the driving force from $573 \mathrm{~K}$ to $593 \mathrm{~K}$ and a large decrease in the driving force from $593 \mathrm{~K}$ to $623 \mathrm{~K}$ are directly proportional to the

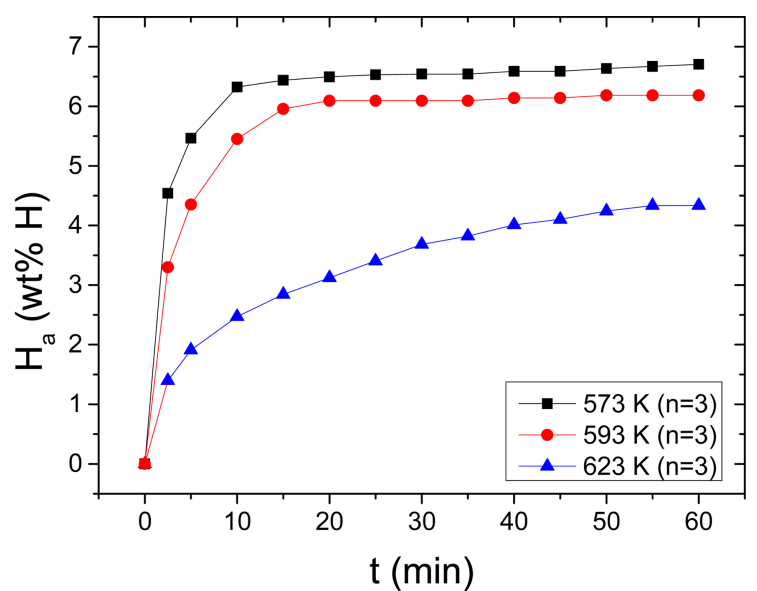

(a)

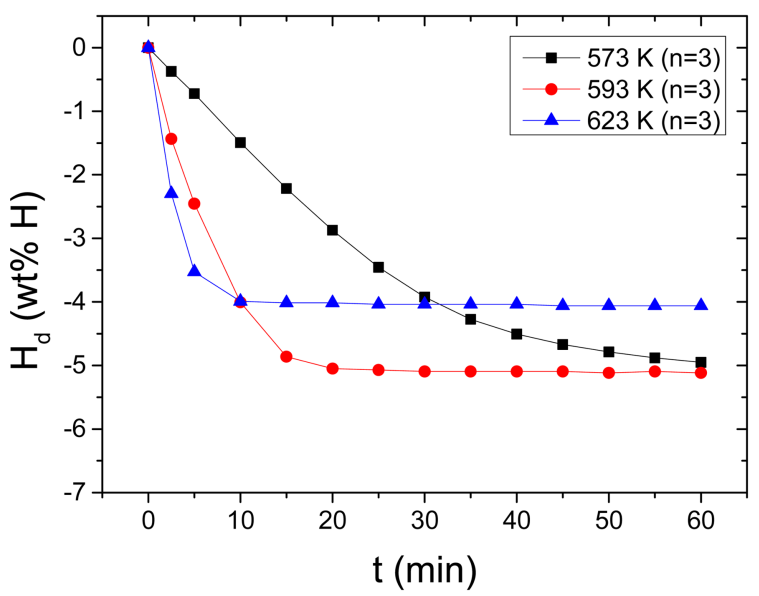

(b)

Fig. 8. Variations in (a) the curve of $\mathrm{H}_{\mathrm{a}}$ as a function of $\mathrm{t}$ in 12 bar $\mathrm{H}_{2}$ and (b) the curve of $\mathrm{H}_{\mathrm{d}}$ as a function of $\mathrm{t}$ in 1.0 bar $\mathrm{H}_{2}$ with temperature $(523 \mathrm{~K}, 573 \mathrm{~K}$, and $623 \mathrm{~K})$ at $\mathrm{n}=3$ for $\mathrm{Mg}-2.5 \mathrm{Ni}-$ 2.5graphene.

decreases in the initial hydrogenation rate and the $\mathrm{H}_{\mathrm{a}}(60$ min) from $573 \mathrm{~K}$ to $593 \mathrm{~K}$ and from $593 \mathrm{~K}$ to $623 \mathrm{~K}$. Table 1 shows the variations in $\mathrm{H}_{\mathrm{a}}(\mathrm{wt} \% \mathrm{H})$ with $\mathrm{t}$ at $573 \mathrm{~K}, 593$ $\mathrm{K}$, and $623 \mathrm{~K}$ in 12 bar $\mathrm{H}_{2}$ at the third cycle for $\mathrm{Mg}-2.5 \mathrm{Ni}-$ 2.5graphene.

The increase in temperature from $573 \mathrm{~K}$ to $593 \mathrm{~K}$ increases greatly the initial dehydrogenation rate. From $593 \mathrm{~K}$ to 623 $\mathrm{K}$, the initial dehydrogenation rate increases fairly. The $\mathrm{H}_{\mathrm{d}}$ (60 min) increases slightly from $573 \mathrm{~K}$ to $593 \mathrm{~K}$ and decreases significantly from $593 \mathrm{~K}$ to $623 \mathrm{~K}$. The $\mathrm{H}_{\mathrm{d}}(60$ $\min )$ at $623 \mathrm{~K}$ is relatively small since a small amount of hydrogen has been absorbed before the dehydrogenation measurement (the $\mathrm{H}_{\mathrm{a}}(60 \mathrm{~min})$ at $623 \mathrm{~K}$ is small). At $593 \mathrm{~K}$, 
Table 1. Variations in $\mathrm{H}_{\mathrm{a}}(\mathrm{wt} \% \mathrm{H})$ with $\mathrm{t}$ at $573 \mathrm{~K}, 593 \mathrm{~K}$, and 623 $\mathrm{K}$ in 12 bar $\mathrm{H}_{2}$ at the third hydrogenation-dehydrogenation cycle for Mg-2.5Ni-2.5graphene.

\begin{tabular}{cccccc}
\hline & $2.5 \mathrm{~min}$ & $5 \mathrm{~min}$ & $10 \mathrm{~min}$ & $30 \mathrm{~min}$ & $60 \mathrm{~min}$ \\
\hline $573 \mathrm{~K}$ & 4.54 & 5.46 & 6.32 & 6.54 & 6.70 \\
\hline $593 \mathrm{~K}$ & 3.30 & 4.35 & 5.45 & 6.09 & 6.18 \\
\hline $623 \mathrm{~K}$ & 1.40 & 1.91 & 2.47 & 3.68 & 4.33 \\
\hline
\end{tabular}

Table 2. Variations in $\mathrm{H}_{\mathrm{d}}(\mathrm{wt} \% \mathrm{H})$ with $\mathrm{t}$ at $573 \mathrm{~K}, 593 \mathrm{~K}$, and 623 $\mathrm{K}$ in $1.0 \mathrm{bar}_{2}$ at the third hydrogenation-dehydrogenation cycle for Mg-2.5Ni-2.5graphene.

\begin{tabular}{cccccc}
\hline & $2.5 \mathrm{~min}$ & $5 \mathrm{~min}$ & $10 \mathrm{~min}$ & $30 \mathrm{~min}$ & $60 \mathrm{~min}$ \\
\hline $573 \mathrm{~K}$ & 0.37 & 0.72 & 1.50 & 3.92 & 4.95 \\
\hline $593 \mathrm{~K}$ & 1.44 & 2.45 & 4.01 & 5.09 & 5.12 \\
\hline $623 \mathrm{~K}$ & 2.30 & 3.53 & 3.99 & 4.04 & 4.06 \\
\hline
\end{tabular}

the quantities of hydrogen released by $\mathrm{Mg}-2.5 \mathrm{Ni}-$ 2.5graphene are $1.44 \mathrm{wt} \% \mathrm{H}$ after $2.5 \mathrm{~min}, 4.01 \mathrm{wt} \% \mathrm{H}$ after $10 \mathrm{~min}$, and $5.12 \mathrm{wt} \% \mathrm{H}$ after $60 \mathrm{~min}$. At $623 \mathrm{~K}$, the quantities of hydrogen released by $\mathrm{Mg}-2.5 \mathrm{Ni}-2.5$ graphene are 2.30, 4.00, and $4.06 \mathrm{wt} \% \mathrm{H}$ after 2.5, 10, and $60 \mathrm{~min}$, respectively. The driving force for dehydrogenation is related to the gap between the equilibrium plateau hydrogen pressure at a dehydrogenation temperature and the pressure for dehydrogenation (1.0 bar $\mathrm{H}_{2}$ in the present work). The equilibrium hydrogen pressures at the plateaus of the pressure-composition isotherms for $\mathrm{Mg}-\mathrm{H}_{2}$ system are 1.55 bar, 2.69 bar, and 7.28 bar at $573 \mathrm{~K}, 593 \mathrm{~K}$, and $623 \mathrm{~K}$, respectively, [28]. The driving forces for dehydrogenation of $\mathrm{MgH}_{2}$ are thus 0.55 bar, 1.69 bar, and 6.28 bar at $573 \mathrm{~K}, 593$ $\mathrm{K}$, and $623 \mathrm{~K}$, respectively. Increase in the driving forces for dehydrogenation of $\mathrm{MgH}_{2}$ with the increase in temperature, together with the effect of temperature increase, is thus believed to increase the initial dehydrogenation rate. Table 2 shows the variations in $\mathrm{H}_{\mathrm{d}}(\mathrm{wt} \% \mathrm{H})$ with $\mathrm{t}$ at $573 \mathrm{~K}, 593 \mathrm{~K}$, and $623 \mathrm{~K}$ in 1.0 bar $\mathrm{H}_{2}$ at the third cycle for $\mathrm{Mg}-2.5 \mathrm{Ni}-$ 2.5graphene.

Figure 9 shows the SEM micrographs at different magnifications of Mg-2.5Ni-2.5graphene after hydrogenationdehydrogenation cycling $(n=4)$. The particle size of $\mathrm{Mg}$ $2.5 \mathrm{Ni}-2.5$ graphene after $\mathrm{n}=4$ is not homogeneous; some particles are large and some particles are small. Some large particles are covered with small particles. The small particles of $\mathrm{Mg}-2.5 \mathrm{Ni}-2.5$ graphene after $\mathrm{n}=4$ is much more numerous than those of $\mathrm{Mg}-2.5 \mathrm{Ni}-2.5$ graphene after

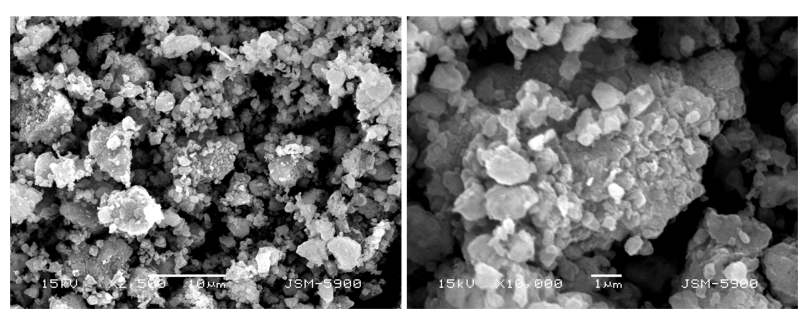

Fig. 9. SEM micrographs at different magnifications of $\mathrm{Mg}-2.5 \mathrm{Ni}-$ 2.5 graphene after hydrogenation-dehydrogenation cycling $(\mathrm{n}=4)$.

reactive ball milling. Expansion and contraction of the particles with hydrogenation-dehydrogenation cycling is believed to have increased the number of small particles.

The XRD pattern of Mg-2.5Ni-2.5graphene after hydrogenation-dehydrogenation cycling $(n=4)$ showed that the sample consisted of $\mathrm{Mg}$ together with small quantities of $\beta-\mathrm{MgH}_{2}$ (JCPDS Card No.12-0697), $\mathrm{MgO}$ (71-1176), $\mathrm{Mg}_{2} \mathrm{Ni}$ (43-0988), and graphene (75-1621). The $\gamma-\mathrm{MgH}_{2}$ phase, which was formed during the reactive ball milling, disappeared. Mechanical energy, which has been stored from mechanical grinding during reactive ball milling, is believed to have been used for the formation of the $\mathrm{Mg}_{2} \mathrm{Ni}$ phase from the reaction of $\mathrm{Mg}$ and $\mathrm{Ni}$ during hydrogenationdehydrogenation cycling. The peaks were narrow and sharp, indicating that the microstrain accumulated during reactive ball milling had been relaxed. The crystallite size of $\mathrm{Mg}$ was calculated using the Scherrer formula as $29 \mathrm{~nm}$, which was about 2.2 times the crystallite size of $\mathrm{Mg}$ after reactive ball milling $(13 \mathrm{~nm})$. The increase in the crystallite size of $\mathrm{Mg}$ after hydrogenation-dehydrogenation cycling suggests that the hydrogenation-dehydrogenation cycling decreases the grain boundary. It is reported that, since the structure of grain boundary is relatively more open than the atomic structure inside grains, the barrier for diffusion through the grain boundary is much less than that through the lattice, and the diffusion rate through grain boundary is higher [29]. The decrease in the grain boundary with hydrogenationdehydrogenation cycling is believed to have contributed in part to the decrease in the hydrogenation and dehydrogenation rates as the number of cycles increases.

Figure 10 shows a micrograph obtained by high-resolution transmission electron microscope (HR-TEM) of Mg- $2.5 \mathrm{Ni}$ 2.5graphene after hydrogenation-dehydrogenation cycling $(n=4)$. The bottom part of the micrograph is the sample 


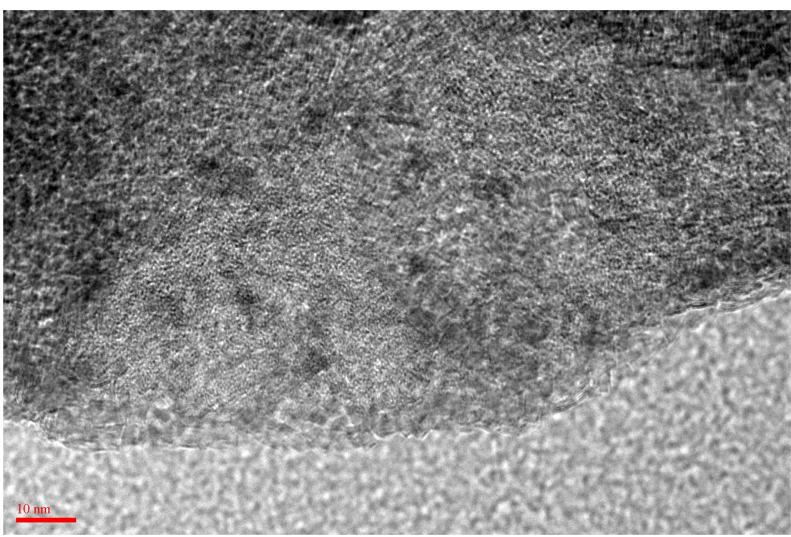

Fig. 10. A HR-TEM micrograph of Mg-2.5Ni-2.5graphene after hydrogenation-dehydrogenation cycling $(\mathrm{n}=4)$.

holder. The sample consists of very fine particles.

It is reported that the graphene added to $\mathrm{MgH}_{\mathrm{x}}$ or $\mathrm{Mg}-\mathrm{Li}$ alloy acts as a catalyst [16,30]. Jang et al. [16], who prepared $\mathrm{MgH}_{\mathrm{x}}$-graphene composites by adding 5 or $10 \mathrm{wt} \%$ graphene to $\mathrm{MgH}_{\mathrm{x}}$ (synthesized by milling in hydrogen) via milling for $72 \mathrm{~h}$ in a planetary ball mill in argon, reported that at $423 \mathrm{~K}$, the added graphene was found to play the role of a hydrogen absorbent as well as a catalyst. Huanjian et al. [30] studied the effects of graphene inclusion on the hydrogenation and dehydrogenation features of $\mathrm{Mg}$-Li alloy. They reported that the addition of graphene could prevent the particles from being agglomerated and make the particles more uniformly distributed in the course of milling. They insisted that graphene acted as a catalyst and thus lowered the apparent activation energy of dehydrogenation for the Mg-Li alloy, which consequently improved the reversibility of the hydrogen absorption and release of the alloy.

Milling mixtures in hydrogen is believed to create imperfections and induce microstrain (resulting in the ease of nucleation), produce fissures and fresh surfaces (resulting in increase in reactivity of the particles with hydrogen), and decrease particle sizes (resulting in decrease in the diffusion distances of hydrogen atoms) [31-37]. Figure 3 shows that the particles of $\mathrm{Mg}-2.5 \mathrm{Ni}-2.5$ graphene after reactive ball milling are much smaller than those of $\mathrm{Mg}-5$ graphene after reactive ball milling. The peaks in the XRD pattern of Mg$2.5 \mathrm{Ni}-2.5$ graphene after reactive ball milling are broader than those in the XRD pattern of Mg-5graphene after reactive ball milling and the XRD pattern of Mg-2.5Ni-2.5graphene after reactive ball milling exhibits the XRD pattern of somewhat amorphous material. The strongest peak of $\mathrm{Mg}$ in the XRD pattern of Mg-2.5Ni-2.5graphene after reactive ball milling has wider full width at half maximum $\left(0.37^{\circ}\right)$ than that of the strongest peak of $\mathrm{Mg}$ in the XRD pattern of Mg-5graphene after reactive ball milling $\left(0.28^{\circ}\right)$ [19]. Milling in hydrogen of a Ni-added $\mathrm{Mg}$ mixture $(95 \mathrm{Mg}+2.5 \mathrm{Ni})$ is believed to create more defects and induce greater microstrain, produce more cracks and clean surfaces, and decrease the particle size more greatly than milling in hydrogen of pure $\mathrm{Mg}$.

Because graphene has a small average specific gravity, graphene has a large specific surface area. Consequently, although a small amount of graphene is included, the added graphene is extensively distributed in the specimen or on the particle surfaces. Since the thermal conductivity of graphene is high, the included graphene is thought to be able to disperse heat rapidly, which is released from the sample during hydrogenation and taken by the specimen from the specimen container during dehydrogenation. The addition of the graphene to the milled $95 \mathrm{Mg}+2.5 \mathrm{Ni}$ mixture is believed to help the sample have higher hydrogenation and dehydrogenation rates by separating particles via dispersion of graphene (leading to the prevention of agglomeration of particles during hydrogenation-dehydrogenation cycling at relatively high temperatures) and by dispersing heat rapidly thanks to high thermal conductivity.

Stronger milling effects on $\mathrm{Mg}$ (creation of defects and induction of microstrain, production of cracks and clean surfaces, and reduction of the particle size) by the addition of $\mathrm{Ni}$ are believed to have made $\mathrm{Mg}-2.5 \mathrm{Ni}-2.5$ graphene have a lower magnesium hydride decomposition temperature. Stronger milling effects on $\mathrm{Mg}$ by the addition of $\mathrm{Ni}$ and the $\mathrm{Mg}_{2} \mathrm{Ni}$ phase formed after cycling in the sample are believed to have made Mg-2.5Ni-2.5graphene have much higher initial hydrogenation and dehydrogenation rates, and significantly larger $\mathrm{H}_{\mathrm{a}}(60 \mathrm{~min})$ and $\mathrm{H}_{\mathrm{d}}(60 \mathrm{~min})$ than $\mathrm{Mg}$ 5graphene.

Hjort et al. [38] reported that mechanical treatment and/or alloying with additives create active nucleation sites and defects, facilitating nucleation. According to the report of Zaluska et al. [39], melding Mg with additives can decrease the magnesium particle size and thus reduce the diffusion distance of hydrogen atoms, and the additives, which produce 
microscopic passages of hydrogen, can increase hydrogen mobility. Vigeholm et al. [40] reported that an uneven surface of magnesium with many fissures and imperfections is considered more favorable for hydrogenation.

The XRD pattern of $\mathrm{Mg}-2.5 \mathrm{Ni}-2.5$ graphene after dehydrogenation-dehydrogenation cycling $(n=4)$ revealed the presence of $\mathrm{Mg}_{2} \mathrm{Ni}$ phase in the sample. The $\mathrm{Mg}_{2} \mathrm{Ni}$ phase is known to have higher hydrogenation and dehydrogenation rates than the $\mathrm{Mg}$ phase. Stronger milling effects of $\mathrm{Mg}$ by the addition of $\mathrm{Ni}$ and the $\mathrm{Mg}_{2} \mathrm{Ni}$ phase formed in the sample are believed to have made $\mathrm{Mg}-2.5 \mathrm{Ni}-2.5$ graphene have lower magnesium hydride decomposition temperature, much higher initial hydrogenation and dehydrogenation rates, a significantly higher efficient capacity of stored hydrogen $\left[\mathrm{H}_{\mathrm{a}}\right.$ (60 min)], and a much larger $\mathrm{H}_{\mathrm{d}}(60 \mathrm{~min})$ than $\mathrm{Mg}-5$ graphene.

The addition of $\mathrm{Ni}$ brings about the stronger milling effects of $\mathrm{Mg}$ and the formation of $\mathrm{Mg}_{2} \mathrm{Ni}$ phase. The addition of the graphene to the milled $95 \mathrm{Mg}+2.5 \mathrm{Ni}$ mixture separates particles via dispersion of graphene (leading to the prevention of agglomeration of particles during cycling at relatively high temperatures) and disperses heat rapidly thanks to high thermal conductivity. These are the synergetic effects of $\mathrm{Ni}$ and graphene addition to $\mathrm{Mg}$. It is known that $\mathrm{Ni}$ has no strong interaction with carbon, differently from other transition elements. This thus brings about no other synergetic effects of the simultaneous $\mathrm{Ni}$ and graphene addition to $\mathrm{Mg}$. Therefore, the effects explained above (the stronger milling effects of $\mathrm{Mg}$, the formation of $\mathrm{Mg}_{2} \mathrm{Ni}$ phase, separation of particles, and dispersing heat rapidly) are believed the main effects of the simultaneous addition of $\mathrm{Ni}$ and graphene. It is still controversial as to whether the hexagonal phase is $\mathrm{Ni}$ carbide or metallic $\mathrm{Ni}$ in many investigations on the synthesis of $\mathrm{Ni}$ nanoparticles because the X-ray diffraction pattern in the International Center for Diffraction Data (ICDD) database of the former is very similar to that of the latter [41]. Fujieda et al. [41] insisted that nanoparticles of $\mathrm{Ni}$ carbide of about $50 \mathrm{~nm}$ in diameter with $\mathrm{Ni}_{3} \mathrm{C}$-type structure were synthesized by the reduction of $\mathrm{Ni}$ salt in a polyol solution in the presence of polyvinylpyrrolidone (PVP). According to a report [42], $\mathrm{Ni}_{3} \mathrm{C}$ is predicted to be nonmagnetic in the ordered phase. Yue et al. [42] prepared the metastable $\mathrm{Ni}_{3} \mathrm{C}$ phase by mechanically alloying $\mathrm{Ni}$ and $\mathrm{C}$ for $90 \mathrm{~h}$. The synthesized
$\mathrm{Ni}_{3} \mathrm{C}$ had the particle diameter of $10 \mathrm{~nm}$ and was disordered and ferromagnetic. We could not find the $\mathrm{Ni}_{3} \mathrm{C}$ phase in the $\mathrm{Mg}-2.5 \mathrm{Ni}-2.5$ graphene samples after reactive ball milling and after hydrogenation-dehydrogenation cycling.

\section{CONCLUSIONS}

$\mathrm{Ni}$ was used as an additive to increase the dehydrogenation rates of graphene-added $\mathrm{Mg}$. Samples (designated as $\mathrm{Mg}$ $2.5 \mathrm{Ni}-2.5$ graphene) with a composition of $95 \mathrm{wt} \% \mathrm{Mg}+2.5$ $\mathrm{wt} \% \mathrm{Ni}+2.5$ graphene were prepared by milling in hydrogen (reactive ball milling). Mg-2.5Ni-2.5graphene had significantly higher initial hydrogenation and dehydrogenation rates and much greater amounts of hydrogen absorbed and released after $60 \mathrm{~min}, \mathrm{H}_{\mathrm{a}}(60 \mathrm{~min})$ and $\mathrm{H}_{\mathrm{d}}(60 \mathrm{~min})$, respectively, than $\mathrm{Mg}-5$ graphene, indicating that the addition of $\mathrm{Ni}$ to the $\mathrm{Mg}-5$ graphene increased the hydrogenation rate as well as the dehydrogenation rate. The addition of $\mathrm{Ni}$ lowered the magnesium hydride decomposition temperature from $683 \mathrm{~K}$ to $581 \mathrm{~K}$. Mg-2.5Ni-2.5graphene had a very high efficient capacity of stored hydrogen (the amount of hydrogen absorbed in $60 \mathrm{~min}$ ) higher than $7 \mathrm{wt} \%$ (7.07 wt\% at $573 \mathrm{~K}$ in 12 bar $\mathrm{H}_{2}$ at $\mathrm{n}=1$ ). The activation of $\mathrm{Mg}-2.5 \mathrm{Ni}-$ 2.5 graphene was finished after $n=2$. At the first cycle at $573 \mathrm{~K}$, the quantities of hydrogen released by $\mathrm{Mg}-2.5 \mathrm{Ni}-$ 2.5 graphene were $0.26 \mathrm{wt} \% \mathrm{H}$ after $2.5 \mathrm{~min}, 0.77 \mathrm{wt} \% \mathrm{H}$ after $10 \mathrm{~min}$, and $3.34 \mathrm{wt} \% \mathrm{H}$ after $60 \mathrm{~min}$ in $1.0 \mathrm{bar}_{2}$. Stronger milling effects on $\mathrm{Mg}$ (creation of defects and induction of microstrain, production of cracks and clean surfaces, and reduction of the particle size) by the addition of $\mathrm{Ni}$ are believed to have made $\mathrm{Mg}-2.5 \mathrm{Ni}-2.5$ graphene have a lower magnesium hydride decomposition temperature. Stronger milling effects on $\mathrm{Mg}$ by the addition of $\mathrm{Ni}$ and the $\mathrm{Mg}_{2} \mathrm{Ni}$ phase formed after cycling in the sample are believed to have made $\mathrm{Mg}-2.5 \mathrm{Ni}-2.5$ graphene have much higher initial hydrogenation and dehydrogenation rates, and significantly larger $H_{a}(60 \mathrm{~min})$ and $H_{d}(60 \mathrm{~min})$ than $\mathrm{Mg}-5$ graphene.

\section{ACKNOWLEDGEMENTS}

This research was supported by Basic Science Research Program through the National Research Foundation of Korea (NRF) funded by the Ministry of Education (grant number 
NRF-2017R1D1A1B03030515). This paper was supported by research funds of Chonbuk National University in 2018.

\section{REFERENCES}

1. M. Y. Song, Y. J. Kwak, S. H. Lee, and H. R. Park, Korean J. Met. Mater. 51, 119 (2013).

2. Y. J. Kwak, H. R. Park, and M. Y. Song, J. Nanosci. Nanotech. 17, 8105 (2017).

3. M. Y. Song, S. H. Lee, Y. J. Kwak, and H. R. Park, J. Nanosci. Nanotech. 17, 8132 (2017).

4. H. R. Park, S. H. Lee, Y. J. Kwak, and M.Y. Song, J. Ceram. Proc. Res. 18, 824 (2017).

5. H. R. Park, Y. J. Kwak, and M. Y. Song, Mater. Res. Bull. 99, 23 (2018).

6. H. R. Park, Y. J. Kwak, and M. Y. Song, Korean J. Met. Mater. 55, 657 (2017).

7. S.-H. Hong, Y. J. Kwak, and M. Y. Song, Korean J. Met. Mater. 56, 59 (2018).

8. S.-H. Hong and M. Y. Song, Korean J. Met. Mater. 56, 155 (2018).

9. M. Y. Song, E. Choi, and Y. J. Kwak, Korean J. Met. Mater. 56, 392 (2018).

10. E. Akiba, K. Nomura, S. Ono, and S. Suda, Int. J. Hydrogen Energy 7, 787 (1982).

11. J.-L. Bobet, E. Akiba, Y. Nakamura, and B. Darriet, Int. J. Hydrogen Energy 25, 987 (2000).

12. M. Y. Song and H. R. Park, Int. J. Hydrogen Energy 18, 653 (1993).

13. J. Huot, H. Hayakawa, and E. Akiba, J. Alloy. Compd. 248 , 164 (1997).

14. A. A. C. Asselli, D. R. Leiva, G. H. Cozentino, R. Floriano, J. Huot, T. T. Ishikawa, and W. J. Botta, J. Alloy. Compd. 615 (Supplement 1), S719 (2014).

15. A. A. C. Asselli, S. F. Santos, and J. Huot, J. Alloy. Compd. 687, 586 (2016).

16. M.-H. Jang, S.-H. Park, and T.-W Hong, Korean J. Met. Mater. 54, 288 (2016)

17. S. Bouaricha, J. P. Dodelet, D. Guay, J. Huot, and R. Schulz, J. Alloy. Compd. 325, 245 (2001).

18. T. Spassov, Z. Zlatanova, M. Spassova, and S. Todorova, Int. J. Hydrogen Energy 35, 10396 (2010).

19. E. Choi, Y. J. Kwak, and M. Y. Song, Met. Mater. Int. 24, 1403 (2018).

20. M. Y. Song, Y. J. Kwak, and E. Choi, Korean J. Met. Mater. 56, $524(2018)$
21. S.-H. Hong, and M. Y. Song, Korean J. Met. Mater. 54, 125 (2016).

22. M. Y. Song, Y. J. Kwak, S. H. Lee, and H. R. Park, Korean J. Met. Mater. 54, 210 (2016).

23. M. Y. Song, Y. J. Kwak, and H. R. Park, Korean J. Met. Mater. 54, 503 (2016).

24. S. N. Kwon, H. R. Park, and M. Y. Song, Korean J. Met. Mater. 54, 510 (2016).

25. Y. J. Kwak, S. H. Lee, and M. Y. Song, J. Nanosci. Nanotech. 18, 6040 (2018).

26. M. Y. Song, Y. J. Kwak, and S. H. Lee, J. Nanosci. Nanotech. 18, 6047 (2018).

27. M. Y. Song, S. H. Baek, J.-L. Bobet, and S. H. Hong, Int. J. Hydrogen Energy 35, 10366 (2010).

28. M. Y. Song and Y. J. Kwak, Korean J. Met. Mater. 56, 244 (2018).

29. https://nptel.ac.in/courses/113108052/module3/lecture17. pdf

30. W. Huanjian, S. Zhenzhen, D. Jiaqi, N. Hua, L. Guangxu, W. Wenlou, L. Zhiqiang, and G. Jin, Mater. Chem. Phys. 207, 221 (2018).

31. Y. J. Kwak, H. R. Park, and M. Y. Song, Met. Mater. Int. 22, 423 (2018).

32. Y. J. Kwak, E. Choi, and M. Y. Song, Met. Mater. Int. 24, 1181 (2018).

33. M. Y. Song, E. Choi, and Y. J. Kwak, Mater. Res. Bull. 108, 23 (2018).

34. M. Y. Song and Y. J. Kwak, Korean J. Met. Mater. 56, 611 (2018).

35. M. Y. Song, E. Choi, and Y. J. Kwak, Korean J. Met. Mater. 56, 620 (2018).

36. M. Y. Song and Y. J. Kwak, Korean J. Met. Mater. 56, 878 (2018).

37. Y. J. Kwak and M. Y. Song, Nanosci. Nanotech. Lett. 10, $772(2018)$

38. P. Hjort, A. Krozer, and B. Kasemo, J. Alloy. Compd. 237 , 74 (1996).

39. A. Zaluska, L. Zaluski, and J. O. Ström-Olsen, J. Alloy. Compd. 288, 217 (1999).

40. B. Vigeholm, J. Kjoller, B. Larsen, and A. S. Pedersen, J. Less-Common Met. 89, 135 (1983).

41. S. Fujieda, K. Shinoda, S. Suzuki, and B. Jeyadevan, Mater. Trans. 53, 1716 (2012).

42. L. Yue, R. Sabiryanov, E. M. Kirkpatrick, and D. L. LesliePelecky, Phys. Rev. B 62, 8969 (2000). 